\title{
Evaluation of physicochemical parameters of grape juices produced in the Serra Gaúcha
}

\author{
Camila Fongaro $^{1}$, Natália Inês Cavagnolli ${ }^{2}$, and Patricia Kelly Wilmsen Dalla Santa Spada ${ }^{1}$ \\ ${ }^{1}$ Faculdade da Serra Gaúcha, Biomedicine Department, Rua Os Dezoito do Forte, $\mathrm{n}^{\circ}$ 2366, Caxias do Sul, RS, Brazil \\ ${ }^{2}$ Universidade de Caxias do Sul, Avenida Francisco Getúlio Vargas, n ${ }^{\circ} 1130$, Caxias do Sul, RS, Brazil
}

\begin{abstract}
The objective of this study was to compare the physicochemical profile of white and purple grape juices through the analysis of reports from the database of an oenological laboratory located in the Serra Gaúcha. The reports of the years 2012 through May of 2016 containing the parameters alcohol, pH, reducing sugars, relative density, titratable acidity, total soluble solids and volatile acidity were used for the statistical evaluation. There was no statistically significant difference regarding the alcohol content and density of white juices compared to purples in any year. Statistically significant $\mathrm{pH}$ values were found in the crops of 2014 and 2015. As for the reducing sugars parameter, it was observed a statistically significant difference in the year of 2014. Titratable acidity was statistically significant in all crops. Statistically significant values of total soluble solids were observed in the harvests of 2014 and 2015. The volatile acidity parameter showed statistical significance in the year 2014. The inherent genetic differences between the varieties of grapes used for each juice and the distinct technological processes used in the production are the factors that explain the results.
\end{abstract}

\section{Introduction}

The grape (Vitis spp.) is one of the most economically important species of plants due to its various uses in the production of wine, grape juice and other food products. Grape crops are one of the main agricultural activities in the world, with more than 60 million tons produced annually [1]. Historically, the production and export of grapes were controlled almost exclusively by traditional European countries, however, in recent years, South America has shown significant growth rate of the production and export of grapes with two harvests per year [2]. In Brazil, the State of Rio Grande do Sul is the main center of grape production, accounting for over $90 \%$ of Brazilian production of grape juices and wines. It has an area of 49.816 hectares, which represents $60.3 \%$ of the total area of grape cultivation of Brazil. The Serra Gaúcha is the most important wine region of the state and therefore the country, where more than $80 \%$ of the total production of grape juice comes from American and hybrid varieties, with a predominance in the cultivation of the species Vitis labrusca (Isabella, referred to as Isabel in Brazil; Concord, and Ives, known as Bordô) which are used to produce grape juice, in addition to the cultivation of the species Vitis vinifera (Cabernet Sauvignon and Merlot) for fine wines [3,4].

According to Brazilian legislation, grape juice is the unfermented beverage, obtained from the simple, sulfided or concentrated must of fresh and ripe grapes, being tolerated the alcoholic graduation until $0.5 \%$ (vol/vol) [5]. Several methodologies are used to produce grape juice, a common one involves the following steps: destemming and crushing, heating, addition of enzymes, juice extraction, clarification, pasteurization and bottling $[6,7]$. In the processing of white grape juices, some producers remove the peels before heating, which is not done with purple juices. The production of grape juices in Brazil is in extensive growth, according to data from the Brazilian Association of Viticulture the production of juices in Rio Grande do Sul rose from almost 28 million liters in 2005 to almost 88 million liters in 2015 , i.e. tripling in volume in a decade. Sales of juices had an even more expressive growth, from almost 38 million liters in 2005 to over 150 million liters in 2015 , almost quadrupling over ten years [8].

Regarding the chemical composition, the grape has a plurality of substances: phenolic compounds such as the anthocyanins, catechins, quercetin, resveratrol and phenolic acids; amino acids and proteins, potassium, sodium, glucose, fructose, and minerals. It is well known that the concentration of polyphenols is greater in purple grape juices than in whites, since that dark colored grapes have higher contents of phenolic compounds and antioxidant capacity [9-12]. Moreover the technology used for preparing the juice, mainly related with the temperature and time of extraction, regulates the intensity of solubility and diffusion of the compounds, from the skin to the must, and is hence a fundamental influence on the chemical composition of the final product [13-17].

In the face of the growing consumption of white and purple grape juices, the objective of this work was to compare the physicochemical profile of these juices from the analysis of reports from a database of an oenological laboratory located in the Serra Gaúcha.

\section{Material and methods}

The reports of physicochemical analysis of the years 2012 to 2016 were kindly provided by an oenological laboratory engaged in the Serra Gaúcha, in the municipality of 
Flores da Cunha, RS. First of all reports of white grape juice samples present in the database were evaluated, then the reports of purple juice samples were copied, whenever possible from the same producer. In a second step, all reports were analyzed and only those with all the following variables were used for the composition of the results: alcohol, $\mathrm{pH}$, reducing sugars, relative density, titratable acidity, total soluble solids and volatile acidity. Statistical evaluation was made in the program SPSS 20.0 for Windows, having been done normality analysis by Levene test, followed by Student's $t$-test for independent samples.

\section{Results and discussion}

There was no statistically significant difference regarding the density and alcohol content of white grape juices compared to purples in any year (Table 1). In general there is great homogeneity in the density values, for which the lowest average for purple grape juices was 1.060 in 2015 and 2016 and the highest was 1.066 in the years 2012 to 2014, while the lowest average observed in white grape juices was 1.060 in 2014 and 2016 and the highest was 1.068 in 2012. Rizzon and Link (2006) [18] analyzed homemade purple grape juices from different varieties and obtained density results on average of 1.055 which are lower than this study's results. Rizzon and Miele (2012) [19] evaluated commercial juices of three types (whole, sweetened and reprocessed), for which average density values were respectively, 1.069, 1.070 and 1.061, showing numbers very compatible with the present work. The lowest average value of alcohol content in purple grape juices was $0.27 \%(\mathrm{v} / \mathrm{v})$ in the harvests of 2012 and 2015 while the highest mean was $0.43 \%$ in 2013 . In white grape juices the lowest average alcohol content was in 2012 in the value of $0.22 \%$, and the highest was $0.50 \%$ in the year 2013. Rizzon and Miele [19] found mean values of alcohol of $0.21 \%$ in whole juices, $0.07 \%$ in sweetened juices and $0.03 \%$ in reprocessed juices available on the market, which are lower than most of the averages found in this study.

As for the reducing sugars parameter, it was observed a statistically significant difference $(p \leq 0.01)$ in the year of 2014, with an average for white grape juices of $13.6 \mathrm{~g} / 100 \mathrm{~g}$, and $14.9 \mathrm{~g} / 100 \mathrm{~g}$ for purple grape juices. This difference is surprising since it's fair to assume that climatic conditions have been similar, however, it is worth noting that it is entirely possible that the grapes originated from different cities, with soils of different compositions, under different technological treatments from the vine to the final product. The combination of these factors probably explains the variation observed. Santana et al. (2008) [20] when comparing whole grape juices available on the market found slightly lower values of reducing sugars of $12.7 \mathrm{~g} / 100 \mathrm{~g}$ for the brand 'A', $11.49 \mathrm{~g} / 100 \mathrm{~g}$ for the ' $\mathrm{B}$ ' and $11.72 \mathrm{~g} / 100 \mathrm{~g}$ for the ' $\mathrm{C}$ '. Carpen and Torezan (2009) [21] obtained values of 12.85 and $11.47 \mathrm{~g} / 100 \mathrm{~g}$ of reducing sugars in two samples of grape juices obtained directly from the producer, lower numbers than this study's data.

Statistically significant $\mathrm{pH}$ values were found in the crops of 2014 (white grape juice: 3.32; purple grape juice: $3.22 ; \mathrm{p} \leq 0.01$ ) and 2015 (white grape juice: 3.25 ; purple grape juice: $3.15 ; \mathrm{p} \leq 0.05$ ). Rizzon and Link [18] found an average of $3.37 \mathrm{pH}$, which is compatible with the results obtained in the present work. Gurak et al. (2008) [22] analyzed commercial whole juices of 8 distinct brands and observed similar values of $\mathrm{pH}$ from 2.94 to 3.58. Santana et al. [20] evaluated three commercial brands of whole grape juice produced in two Brazilian regions, obtaining the results of 3.50 (brand 'A'), 3.18 (brand 'B') and 3.42 (brand ' $\mathrm{C}$ '), all of them akin to this work. Carpen and Torezan [21] observed results of 3.13 (sample 'A') and 4.10 (sample 'B'), the latter being a much higher number than the highest observed in this study (3.59 for a white grape juice in the year of 2013). Burin et al. [11] analyzed 3 homemade grape juices for which $\mathrm{pH}$ values were 3.30, 3.51 and $3.64 ; 7$ commercial juices which varied from 3.25 to 3.56 and 2 organic juices with measurements of 3.32 and 3.40 , their results were compatible with this work. Canadian researchers [23] prepared juices from 10 different cultivars and found $\mathrm{pH}$ values of 2.38 to 3.13 , displaying a lower number than the lowest observed in this study (2.81 for a white grape juice from the crop of 2013). Gabardo et al. (2015) [24] evaluated the protective effect of white grape juice in rats and observed a $\mathrm{pH}$ of 3.89 in organic white grape juice and 3.58 in conventionally produced white grape juice, those being notably high values compared to the means of the present work.

Of the seven variables considered the only one that was statistically significant $(\mathrm{p} \leq 0.01)$ in all crops was the titratable acidity. The values of white grape juices were always lower than that of purple grape juices. This is explained by the inherent genetic differences of the varieties used for the production of each juice. The cultivar most used for the production of white grape juice is the Niagara, while the varieties Ives (typically referred to as Bordô in southern Brazil), Concord, and Isabella (known as Isabel in the south of Brazil) are the most employed for the elaboration of purple grape juices. Moreover, the production technology used in juice processing, regardless of grape variety, can result in different levels of extraction of the substances contained in the grape $[3,12,17]$.

The volatile acidity parameter showed statistical significance in the year 2014, the mean value for white samples was $0.021 \mathrm{~g} / 100 \mathrm{~g}$ of acetic acid, and 0.013 for purples. Rizzon and Miele [19] found values of $0.03 \mathrm{~g} / 100 \mathrm{~g}$ of acetic acid for whole juices, $0.05 \mathrm{~g} / 100 \mathrm{~g}$ of acetic acid for sweetened juices and $0.02 \mathrm{~g} / 100 \mathrm{~g}$ of acetic acid for the reprocessed juice, which are lower values than most found in this study. Gabardo et al. [24] observed volatile acidity of $0.04 \mathrm{~g} / 100 \mathrm{~g}$ of acetic acid for both conventionally produced and organic white grape juice, those being low numbers when compared to the present work.

Statistically significant values of total soluble solids (TSS) were observed in the harvests of 2014 and 2015. In 2014 the white grape juices showed lower values $(\mathrm{p} \leq 0.01)$ than the purples: 15.1 and $16.2^{\circ}$ Brix, respectively. Yet in 2015 ( $\mathrm{p} \leq 0.05$ ) the opposite happened, the average TSS of white samples was $15.8^{\circ}$ Brix while of purples was $15.0^{\circ}$ Brix. Rizzon and Link [19] found lower values of 12.2 to $13.1^{\circ}$ Brix. Gurak et al. [22] obtained data from 14.0 to $16.9^{\circ}$ Brix, which are compatible with this work. Santana et al. [20] observed similar results of $14.21,15.20$ and $17.30^{\circ}$ Brix in three different brands of juice marketed in the midwestern and southeastern regions of Brazil. Burin et al. [11] analyzed 3 homemade 
Table 1. Average of the parameters evaluated in white and purple grape juices in a laboratory of Flores da Cunha, RS, in the period 2012 to 2016 .

\begin{tabular}{|c|c|c|c|c|c|c|c|c|}
\hline \multirow{2}{*}{ Crop } & \multirow{2}{*}{ Samples (n) } & \multicolumn{7}{|c|}{ Mean values $( \pm \mathrm{SD})[\min -\max ]$} \\
\hline & & $\begin{array}{l}\text { Density } \\
\left(20 / 20^{\circ} \mathrm{C}\right)\end{array}$ & \begin{tabular}{|l} 
Alcohol \\
$(\%$ v/v)
\end{tabular} & $\begin{array}{l}\text { Reducing } \\
\text { sugars }(\mathrm{g} / 100 \mathrm{~g})\end{array}$ & $\mathrm{pH}$ & $\begin{array}{l}\text { Titratable acidity } \\
\text { (g/100g tartaric } \\
\text { acid) }\end{array}$ & $\begin{array}{l}\text { Volatile acidity } \\
\text { (g/100g acetic } \\
\text { acid) }\end{array}$ & \begin{tabular}{|l|} 
Total Soluble \\
Solids $\left({ }^{\circ}\right.$ Brix $)$
\end{tabular} \\
\hline \multirow[t]{2}{*}{2012} & White (7) & $\begin{array}{l}1.068 \pm 0.003 \\
{[1.06-1.07]}\end{array}$ & $\begin{array}{l}0.22 \pm 0.08 \\
{[0.17-0.40]}\end{array}$ & $\begin{array}{l}15.1 \pm 0.3 \\
{[14.6-15.8]}\end{array}$ & $\begin{array}{l}3.31 \pm 0.07 \\
{[3.20-3.43]}\end{array}$ & $\begin{array}{l}0.41 \pm 0.02 * * \\
{[0.36-0.45]}\end{array}$ & $\begin{array}{l}0.011 \pm 0.004 \\
{[0.003-0.017]}\end{array}$ & \begin{tabular}{|l|}
$16.4 \pm 0.3$ \\
{$[15.9-17.0]$}
\end{tabular} \\
\hline & Purple (8) & $\begin{array}{l}1.066 \pm 0.005 \\
{[1.06-1.07]} \\
\end{array}$ & \begin{tabular}{|l|}
$0.27 \pm 0.07$ \\
{$[0.14-0.37]$} \\
\end{tabular} & \begin{tabular}{|l|}
$14.8 \pm 1.2$ \\
{$[13.2-16.7]$} \\
\end{tabular} & $\begin{array}{l}3.25 \pm 0.06 \\
{[3.17-3.37]}\end{array}$ & $\begin{array}{l}0.75 \pm 0.09 \\
{[0.60-0.90]}\end{array}$ & \begin{tabular}{|l|}
$0.017 \pm 0.007$ \\
{$[0.009-0.028]$} \\
\end{tabular} & \begin{tabular}{|l|}
$16.1 \pm 1.1$ \\
{$[14.7-17.9]$} \\
\end{tabular} \\
\hline \multirow[t]{2}{*}{2013} & $\mathrm{~W}$ & $\begin{array}{l}1.065 \pm 0.005 \\
{[1.06-1.08]}\end{array}$ & $\begin{array}{l}0.50 \pm 0.39 \\
{[0.14-1.59]}\end{array}$ & $\begin{array}{l}14.6 \pm 1.5 \\
{[12.1-18.3]}\end{array}$ & $\begin{array}{l}3.19 \pm 0.17 \\
{[2.81-3.59]}\end{array}$ & $\begin{array}{l}0.51 \pm 0.09 * * \\
{[0.31-0.75]}\end{array}$ & $\begin{array}{l}0.019 \pm 0.009 \\
{[0.001-0.041]}\end{array}$ & \begin{tabular}{|l}
$15.9 \pm 1.3$ \\
{$[13.7-19.3]$}
\end{tabular} \\
\hline & Purt & $\begin{array}{l}1.066 \pm 0.008 \\
{[1.04-1.08]}\end{array}$ & $\begin{array}{l}0.43 \pm 0.56 \\
{[0.16-2.94]}\end{array}$ & $\begin{array}{l}15.2 \pm 1.8 \\
{[8.9-18.4]}\end{array}$ & $\begin{array}{l}3.16 \pm 0.10 \\
{[3.03-3.39]}\end{array}$ & $\begin{array}{l}0.80 \pm 0.17 \\
{[0.57-1.32]}\end{array}$ & $\begin{array}{l}0.016 \pm 0.012 \\
{[0.003-0.062]}\end{array}$ & \begin{tabular}{|l|}
$16.4 \pm 1.7$ \\
{$[10.5-19.3]$} \\
\end{tabular} \\
\hline \multirow[t]{2}{*}{2014} & Whit & $\begin{array}{l}1.060 \pm 0.000 \\
{[1.06-1.06]}\end{array}$ & \begin{tabular}{|l|}
$0.30 \pm 0.14$ \\
{$[0.00-0.56]$}
\end{tabular} & $\begin{array}{l}13.6 \pm 0.5 * * \\
{[12.9-14.5]}\end{array}$ & $\begin{array}{l}3.32 \pm 0.06^{* *} \\
{[3.16-3.43]}\end{array}$ & $\begin{array}{l}0.48 \pm 0.06^{* *} \\
{[0.40-0.60]}\end{array}$ & $\begin{array}{l}0.021 \pm 0.013^{*} \\
{[0.003-0.050]}\end{array}$ & \begin{tabular}{|l}
$15.1 \pm 0.5^{* *}$ \\
{$[14.4-15.8]$}
\end{tabular} \\
\hline & Pur & $\begin{array}{l}1.066 \pm 0.004 \\
{[1.06-1.07]}\end{array}$ & $\begin{array}{l}0.32 \pm 0.11 \\
{[0.19-0.52]}\end{array}$ & $\begin{array}{l}14.9 \pm 1.0 \\
{[13.2-16.4]}\end{array}$ & $\begin{array}{l}3.22 \pm 0.07 \\
{[3.09-3.41]}\end{array}$ & $\begin{array}{l}0.74 \pm 0.15 \\
{[0.55-1.02]}\end{array}$ & $\begin{array}{l}0.013 \pm 0.004 \\
{[0.006-0.024]}\end{array}$ & \begin{tabular}{|l|}
$16.2 \pm 0.8$ \\
{$[14.5-17.5]$}
\end{tabular} \\
\hline \multirow[t]{2}{*}{2015} & Whit & $\begin{array}{l}1.065 \pm 0.006 \\
{[1.05-1.07]}\end{array}$ & \begin{tabular}{|l|}
$0.31 \pm 0.12$ \\
{$[0.00-0.47]$}
\end{tabular} & $\begin{array}{l}14.5 \pm 1.4 \\
{[11.7-15.9]}\end{array}$ & $\begin{array}{l}3.25 \pm 0.11^{*} \\
{[3.06-3.46]}\end{array}$ & $\begin{array}{l}0.60 \pm 0.15^{* *} \\
{[0.07-0.75]}\end{array}$ & \begin{tabular}{|l|}
$0.012 \pm 0.003$ \\
{$[0.005-0.022]$}
\end{tabular} & \begin{tabular}{|l|}
$15.8 \pm 1.2^{*}$ \\
{$[13.3-17.1]$}
\end{tabular} \\
\hline & Purple (22) & $\begin{array}{l}1.060 \pm 0.005 \\
{[1.05-1.07]} \\
\end{array}$ & \begin{tabular}{|l|}
$0.27 \pm 0.07$ \\
{$[0.16-0.46]$}
\end{tabular} & \begin{tabular}{|l|}
$13.6 \pm 1.1$ \\
{$[11.2-15.85]$} \\
\end{tabular} & $\begin{array}{l}3.15 \pm 0.09 \\
{[2.84-3.28]}\end{array}$ & $\begin{array}{l}0.89 \pm 0.25 \\
{[0.63-1.72]}\end{array}$ & $\begin{array}{l}0.013 \pm 0.005 \\
{[0.005-0.028]}\end{array}$ & \begin{tabular}{|l|}
$15.0 \pm 1.0$ \\
{$[12.8-17.1]$} \\
\end{tabular} \\
\hline \multirow[t]{2}{*}{2016} & White (12) & $\begin{array}{l}1.060 \pm 0.007 \\
{[1.05-1.07]}\end{array}$ & $\begin{array}{l}0.35 \pm 0.10 \\
{[0.20-0.51]}\end{array}$ & $\begin{array}{l}13.2 \pm 1.6 \\
{[10.8-15.4]}\end{array}$ & $\begin{array}{l}3.31 \pm 0.11 \\
{[3.21-3.58]}\end{array}$ & $\begin{array}{l}0.69 \pm 0.13^{* *} \\
{[0.47-0.96]}\end{array}$ & $\begin{array}{l}0.03 \pm 0.02 \\
{[0.008-0.063]}\end{array}$ & $\begin{array}{l}14.7 \pm 0.5 \\
{[12.4-16.8]}\end{array}$ \\
\hline & Pur| & $\begin{array}{l}1.060 \pm 0.000 \\
{[1.06-1.06]}\end{array}$ & $\begin{array}{l}0.39 \pm 0.11 \\
{[0.24-0.63]}\end{array}$ & $\begin{array}{l}13.3 \pm 0.5 \\
{[12.5-14.3]}\end{array}$ & $\begin{array}{l}3.24 \pm 0.09 \\
{[3.00-3.36]}\end{array}$ & $\begin{array}{l}1.09 \pm 0.19 \\
{[0.83-1.46]}\end{array}$ & $\begin{array}{l}0.02 \pm 0.01 \\
{[0.004-0.060]}\end{array}$ & $\begin{array}{l}14.6 \pm 0.4 \\
{[13.9-15.4]}\end{array}$ \\
\hline
\end{tabular}

SD: standard deviation; min: minimum value for each parameter; max: maximum value for each parameter. *p $\leq 0.05 ; * * \mathrm{p} \leq 0.01$. Significantly different values by the $t$-test for independent samples, considering the samples of white and purple juices, per harvest.

Table 2. Analytical limits established by Brazilian legislation for grape juice.

\begin{tabular}{|l|c|c|}
\hline \multirow{2}{*}{ Parameter } & \multicolumn{2}{|c|}{ Limit } \\
\cline { 2 - 3 } & Minimum & Maximum \\
\hline Relative density at $20 / 20^{\circ} \mathrm{C}$ & 1.057 & - \\
\hline Ethanol, \% v/v & - & 0.50 \\
\hline Total sugars, g/100g & - & 20.00 \\
\hline $\begin{array}{l}\text { Titratable acidity, } \\
\text { g/100g tartaric acid }\end{array}$ & 0.41 & - \\
\hline $\begin{array}{l}\text { Volatile acidity, } \\
\text { g/100g acetic acid }\end{array}$ & - & 0.050 \\
\hline $\begin{array}{l}\text { Soluble solids, } \\
{ }^{\circ} \text { Brix at } 20^{\circ} \mathrm{C}\end{array}$ & 14.00 & - \\
\hline
\end{tabular}

Source: Ministry of Agriculture, Livestock and Supply - Normative Instruction no. 24 , of 16 December 2005 .

grape juices for which values of TSS were 10.0, 19.0 and $21.5^{\circ}$ Brix; 7 commercial juices that ranged from 9.5 to $16^{\circ}$ Brix and 2 organic juices with measurements of 15.0 and $12.0^{\circ}$ Brix, having found both higher and lower values than the highest $\left(19.3^{\circ}\right.$ Brix for white and purple grape juices in 2013) and the lowest $\left(10.5^{\circ}\right.$ Brix of a purple grape juice from 2013) results found in the present work. Rizzon and Miele [19] observed analogous values of $16.2^{\circ}$ Brix for whole juices, $16.5^{\circ}$ Brix for sweetened juices and $14.0^{\circ}$ Brix for reprocessed juices.

The average of all the variables in all harvests, for both varieties of juice (white and purple), fall within the limits required by Brazilian legislation (Table 2).

However observing the minimum and maximum values it can be seen that some variables are in disagreement with the law (Table 3). In view of these discrepancies, it is important to mention that the analyzes
Table 3. Assessment of the physicochemical parameters analyzed against the current legislation.

\begin{tabular}{|c|c|c|c|c|c|}
\hline \multirow{2}{*}{ Parameters } & \multicolumn{5}{|c|}{ Crop } \\
\hline & 2012 & 2013 & 2014 & 2015 & 2016 \\
\hline Density & LA & $1 \mathrm{P} \downarrow$ & LA & LA & LA \\
\hline Alcohol & LA & $\begin{array}{l}1 \mathrm{~W} \uparrow \\
1 \mathrm{P} \uparrow\end{array}$ & $\begin{array}{c}1 \mathrm{~W} \uparrow \\
1 \mathrm{P} \uparrow\end{array}$ & LA & $\begin{array}{c}1 \mathrm{~W} \uparrow \\
1 \mathrm{P} \uparrow\end{array}$ \\
\hline $\begin{array}{l}\text { Reducing } \\
\text { sugars }\end{array}$ & $\overline{\mathrm{LA}}$ & LA & $\mathrm{LA}$ & $\overline{\mathrm{LA}}$ & LA \\
\hline $\begin{array}{l}\text { Titratable } \\
\text { acidity }\end{array}$ & $1 \mathrm{~W} \downarrow$ & $1 \mathrm{~W} \downarrow$ & $1 \mathrm{~W} \downarrow$ & $1 \mathrm{~W} \downarrow$ & LA \\
\hline $\begin{array}{l}\text { Volatile } \\
\text { acidity }\end{array}$ & LA & $1 \mathrm{P} \uparrow$ & LA & LA & $\begin{array}{l}1 \mathrm{~W} \uparrow \\
1 \mathrm{P} \uparrow\end{array}$ \\
\hline $\begin{array}{l}\text { Total } \\
\text { soluble } \\
\text { solids }\end{array}$ & LA & $\begin{array}{l}1 \mathrm{~W} \downarrow \\
1 \mathrm{P} \downarrow\end{array}$ & LA & $1 \mathrm{~W} \downarrow 1 \mathrm{P} \downarrow$ & $\begin{array}{l}1 \mathrm{~W} \downarrow \\
1 \mathrm{P} \downarrow\end{array}$ \\
\hline
\end{tabular}

LA: law-abiding; W: white juice; P: purple juice; $\uparrow:$ value above the maximum; $\downarrow$ : value below the minimum.

were made in juices in the process of drafting, and not completed and available products on the market, as such it is expected that the items have been adjusted to fit the legislation.

\section{Conclusions}

Through this comparison between purple and white grape juices, we observe that there are significant differences in physicochemical parameters among the products. The following factors explain such data: (a) distinct technological procedures employed to create both types of juice and (b) inherent genetic differences of the varieties used in the production of each juice. 


\section{References}

[1] A. Teixeira, N. Baenas, R. Dominguez-Perles, A. Barros, E. Rosa, D.A. Moreno, C. GarciaViguera, Int. J. Mol. Sci., 15, 9, 15638-15678 (2014)

[2] E.C. Sousa, A.M.A. Uchôa-Thomaz, J. Osvaldo, B. Carioca, S.M. Morais, A. Lima, A. C.G. Martins, C.D. Alexandrino, P. Augusto, T. Ferreira, A. Livya, M. Rodrigues, S.P. Rodrigues, N. Silva, L.L. Rodrigues, Food Sci. Technol. (Campinas), 34, 1, 135-142 (2014)

[3] N. Poerner, E. Rodrigues, P.G. Celso, V. Manfroi, P.F. Hertz, P. F. Cienc Rural, 40, 5, 1186-1192 (2010)

[4] M.J.R. Da Silva, M.A. Tecchio, M.F. Moura, L.T. Brunelli, V.M. Imaizumi, W.G.V. Filho, Pesq. agropec. bras., 50, 11, 1105-1113 (2015)

[5] Brasil. Ministério da Agricultura, Pecuária e Abastecimento. Instrução Normativa $\mathrm{n}^{\circ}$ 24, de 16 de Dezembro de 2005. Diário Oficial da União. Brasilia, DF (2005)

[6] L.A. Rizzon, J. Meneguzzo, Suco de uva, 1, 45 (2007)

[7] R. Clemens, A. Drewnowski, M.G. Ferruzzi, C.D. Toner, D. Welland, Adv Nutr, 6, 2, 236S-243S (2015)

[8] L.M.R. Mello, C.A.E. Machado, available at: <http://vitibrasil.cnpuv.embrapa.br/>, accessed in April $5^{\text {th }}$ (2016)

[9] L.T. Abe, R.V. Da Mota, F.M. Lajolo, M.I. Genovese, Food Sci. Technol. (Campinas), 27, 2, 394-400 (2007)

[10] C. Dani, L.S. Oliboni, R. Vanderlinde, D. Bonatto, M. Salvador, J.A.P. Henriques, Food Chem. Toxicol., 45, 12, 2574-2580 (2007)
[11] V.M. Burin, L.D. Falcão, L.V. Gonzaga, R. Fett, J.P. Rosier, M.T. Bordignon-Luiz, Food Sci. Technol. (Campinas), 30, 4, 1027-1032 (2010)

[12] D. Granato, M. De Magalhães Carrapeiro, V. Fogliano, S.M.V. Ruth, Trends Food Sci. Technol., 52, 31-48 (2016)

[13] T. Garde-Cerdán, M. Arias-Gil, A.R. MarsellésFontanet, C. Ancín-Azpilicueta, O. Martín-Belloso, Food Control, 18, 5, 473-479 (2007)

[14] A.R. Marsellés-Fontanet, O. Martín-Belloso, J. Food Eng., 83, 3, 452-462, (2007)

[15] F. İçiér, H. Yildiz, T. Baysal, J. Food Eng., 85, 3, 410 417 (2008)

[16] R. González-Barrio, M.L. Vidal-Guevara, F.A. Tomás-Barberán, J.C. Espín, Innov. Food Sci. Emerg. Technol., 10, 3, 374-382 (2009)

[17] B.K. Tiwari, A. Patras, N. Brunton, P.J. Cullen, C.P. O’Donnell, Ultrason Sonochem, 17, 3, 598-604 (2010)

[18] L.A RIZZON, M. LINK, Cienc Rural, 36, 2, 689-692 (2006)

[19] L.A. Rizzon, A. Miele, Food Sci. Technol. (Campinas), 32, 1, 93-97 (2012)

[20] M.T.A. Santana, H.H. De Siqueira, K.C. Dos Reis, L.C. De Oliveira Lima, R.J.L. Silva, Ciênc. agrotec., 32, 3, 882-886 (2008)

[21] K. Carpen, A. Torezan, Ágora, 16, 2, 351-361 (2009)

[22] P.D. Gurak, M.C. Silva, V.M. Da Matta, M.H. Rocha-Leão, L.M.C. Cabral, Rev. Ciênc. Exatas, 27, 1-2, 1-15 (2008)

[23] C.C. Ratnasooriya, H.P.V. Rupasinghe, A.R. Jamieson, Can. J. Plant Sci., 90, 193-205 (2010)

[24] T. Gabardo, C.M. Peripolli, R.B. De Andrade, T. Gemelli, J.D.O. Lima, A.S. Oliveira, N. Da Silva Medeiros, C. Wannmacher, C. Dani, C. Funchal, Toxicol Rep, 2, 645-653 (2015) 